\title{
Reinforcing Property by Strengthening the Commons: A New Media Policy Paradigm?
}

\author{
Peter Jakobsson* and Fredrik Stiernstedt** \\ * School of Culture \& Communication, Södertörn University, Huddinge, Sweden, \\ peter.jakobsson@sh.se \\ ${ }^{* *}$ School of Culture \& Communication, Södertörn University, Huddinge, Sweden, \\ fredrik.stiernstedt@sh.se
}

\begin{abstract}
In much scholarly writing and in many leftist and activist accounts the enclosures of the cultural commons have been fiercely critiqued. However, during the last years, new media business models, that challenge the notion of the cultural industries as "copyright industries", has been taking shape. A new class of entrepreneurs is instead working to expand the commons as part of their businesses. Accordingly, representatives from these new media industries, policy makers, and politicians have joined the academic and political critique of the "enclosures of the cultural common". The paper argues that this is a shift within the dominant media policy paradigm and an attempt to integrate existing practices on the Internet, based on cooperation and sharing, into the market. By relocating the struggle from "intellectual property" to "platform economics", the media industry can exploit the productivity of the commons while holding on to the power that comes with ownership and property.
\end{abstract}

Keywords: Cultural Commons; Digital Enclosures; Media Policy; Social Media; Capitalism; Critical Political Economy

The developments and changes in media technologies and practices during the last decade have moved the concept of the "common" to the centerfield of critical attention in the political economy of the Internet. Social media, web 2.0, file sharing, free software, and wikis are examples of phenomena theorized with the help of this concept (Dyer-Witheford 2002; Benkler 2006). Writers from the whole political spectrum ranging from left to right have understood the commons as representing an alternative to state- or private property and/or as an alternative mode of organizing production (Caffentzis 2010). The aforementioned technologies, carrying a seed of a future commons, have thus been understood as harbingers of radical social change. "Communism", writes Antonio Negri, "begins to take shape when the proletarian takes it as her objective to re-appropriate the Gemeinwesen, the community, to turn it into the order of a new society" (Negri 2010, 156). The digital commons have been identified as one such possible space for this re-appropriation to occur.

The struggle over the commons is usually understood as involving, on the one hand the so called "copyright industries" (Wikström 2006), and on the other academics and activists, socialists, communists, leftists, and liberals that from various positions have come together in a critique of the enclosure of the commons. What has been critiqued is firstly the attempts from corporations and states to limit access to cultural commons by the expansion and intensification of private property rights in the immaterial realm (Lessig 2004; Benkler 2006), and secondly, the corporate attempts to enclose, privatize and commercialize the social production on the internet with the Internet "platform" as the primary tool (Andrejevic 2007; Jakobsson and Stiernstedt 2010). Contemporary business models, and the developments within the networked digital economy, can increasingly, it has been argued, be understood as processes of "accumulation by dispossession" (Marx 1867/1976): the generation of profits through irregular means, through a second enclosure movement (Boyle 2003). Both legal and technological forms are part of this enclosure movement, and copyrights and digital platforms have been seen as equivalents to fences, by which Capital encloses materials that previously belonged to cultural commons.

These two types of enclosures however differ from each other and from the fences that enclosed the fields and pastures in the "first" enclosure movement. The legal forms of patents and copyrights are similar to fences in that they exclude people from a resource or means of production. The digital platforms do not separate people from the means of production and do not forbid activity and production. On the contrary, as we have argued elsewhere, the digital enclosure, paradoxically "strives for informational and communicative excess through promoting freedom and openness, and enhancing certain types of communication" (Jakobsson and Stiernstedt 2010). Digital enclosures are thus often both enclosures and commons at the same time and the ideology of many new digital media industries (social networking sites, platforms for content sharing and distri- 
bution) is consequently infused with values such as openness, availability, participation, commonsbased production, and cooperation. Consequently, the business practices and ideology of the digital media industry make it sometimes seem like its values are the same as those of the critics of the second enclosure movement and that the digital media industry hence partake in the (radical) critique of the copyright industries.

The purpose of this article is to investigate further this "alliance" between the critics of the enclosure movement and the digital media industries: and to analyse the ideological side of the media industries' and media policy makers' adoption of a vocabulary of openness and participation. In order to explore this question, the article is divided into three parts. The first part is a theoretical discussion that takes up points from David Harvey (2003) and Michael Hardt and Antonio Negri (2009) on the dialectical relationship between capital and commons. Secondly, we provide some examples relating to the development of contemporary media policies, by which the simultaneous enclosing and "opening up" of cultural production and ownership is performed. Thirdly, we suggest how what we describe in the paper can be understood as a reorientation within the dominant "media policy paradigm" (van Cuilenberg and McQuail 2003). This reorientation focuses on the attempt to exploit the productivity of the commons while at the same time reinforcing the power of capital. We propose that platform economics is a way of reinforcing the power of property and ownership when the struggle over intellectual property is failing.

\section{Enclosures}

The historical background to the contemporary critique of the enclosure of the commons is the original enclosure movement that took place in Europe during a period from the middle ages until the $19^{\text {th }}$ century. During this period, vast areas of land, previously managed in common, were enclosed to become private property in the hands of a new class of landowners (Neeson 1993). This process has been given a central place in the critical tradition much due to the historical description and analysis given by Karl Marx (1867/1976) in volume one of Capital. Marx gives the enclosure movement a central role in the transition from feudalism to capitalism and consequently sees it as entailing a dialectic relationship between enslavement and liberation. The peasants lost their traditional and inherited rights to the land and were "set free" to sell their labour to the nascent class of industrialists, a freedom that, however, paved the way for new forms of enslavement in the factories owned by the new industrialist class. In the works of the classical economists and in the critique developed by Marx, the enclosure movement has been known as primitive accumulation, which signals the constitutive role the enclosure movement had in creating the capital needed for setting up a capitalist economy. As a critical tool, however, the enclosure is a metaphor that has been used to understand processes within capitalism with a similar dynamics or with similar effects.

In this paper, we use David Harvey's (2003) discussion of Rosa Luxemburg (1913/2003) to stress the continued importance of the relationship between capital and commons. What characterizes the capitalist economy, according to Luxemburg, are two distinct forms of accumulation. First, the well-known exchange of commodities, ruled by law and relations of the market, and, secondly, forms of accumulation that take place through interaction with things that lie outside of the regular capitalist economy, for example, in the imperialist relations between Europe and the rest of the world and between the capitalist economy concentrated in the city and the peasant (gift) economies remaining in the countryside. The second form of accumulation does not abide to the laws of the regular market, but on the contrary often involves fraud and theft and is frequently accompanied by violence. According to Luxemburg, the primitive accumulation - the enclosure of the commons - is hence not something that only took place once, in the transition from feudalism to capitalism, but something that constantly repeats itself in areas characterized as the peripheries of capitalism. Harvey names this process accumulation by dispossession (Harvey 2003, 137).

Harvey chooses however not to theorize accumulation by dispossession as a relation between the geographical centres and peripheries of capitalism. Instead, he understands it as a relation between the inside and the outside of the capitalist economic system: a dynamic relationship that has its place also within the geographical core of capitalism. Harvey includes a range of processes and phenomena in the understanding of accumulation by dispossession: the new imperialism and the commercialization of natural resources; the privatization of land and the branding of cities; credit- and finance systems and their catastrophic impact on national economies; the privatization of state financed infrastructure and state financed welfare systems (hospitals, schools, etc), and most relevant for our purposes, the formation of a global regulative regime for so-called intellectual property, which means patents, copyrights, and brands. This regulative regime has been successfully deployed in order to commodify traditional narratives, songs, local knowledge and other cultural expressions, which previously were part of the common. 
Harvey's discussion of accumulation by dispossession shares several features with how Michael Hardt and Antonio Negri (2009) conceptualize the situation of the commons in their book Commonwealth. With a broad outlook on the ongoing enclosure movement (the move towards "biopolitical production") they focus on how: "[n]eoliberal government policies throughout the world have sought in recent decades to privatize the common, making cultural products - for example, information, ideas, and even species of animals and plants - into private property" (Hardt and Negri 2009, viii). They argue that the bulk of earth's natural resources already has been colonized and privatized and that the struggle of interest at the moment is the struggle over immaterial and symbolic resources that we still own in common. These resources are increasingly understood as having (potential) economic value as a consequence of the technical development and the transition from industrial- to post-industrial society. Just like Harvey, Hardt and Negri observe that the relationship between capital and the commons is not only a matter of the former overtaking the latter, but also a relationship of dependence. The commons can exist without capital, but capital is dependent on the commons. Harvey makes the general observation that capital always needs an outside in order to find new opportunities for investment and growth, whereas Hardt and Negri see this circumstance as typical for post-Fordist capitalism, where knowledge and culture are primary sources of economic value. Since ideas, images, and affects are productive in so far that they are shared, the enclosure of the cultural commons is limiting the growth of capital: "the more the common is corralled as property, the more its productivity is reduced" (Hardt 2010, 136). We argue that the emergence of the new policy discourse on media that is analysed in the next part of the article is due to these ambivalences and ambiguities within the relationship between capital and commons.

\section{Media Policy and the Critique of the Enclosure of the Commons}

During the last decades media policy has been heading in the direction towards longer and stronger protection of intellectual property: a choice that has been motivated on the grounds of strengthening the so-called creative industries (Kretschmer 2005; Flew 2005). What has happened during the last years, however, is that the well-established tradition within leftist, but also liberal circles, of critiquing the enclosure of the commons, has been accompanied by new voices from within the media industries and from media policy-makers. The rather one-sided defence of copyrights and trademarks that has been a staple of media industry rhetoric - to the extent that it has been suggested that we should talk about them as copyright industries (Wikström 2006) - has been supplemented with new voices that are questioning the effectiveness of copyright on economic grounds. Naturally, the cultural and media industries are not monolithic and within them, different interests have always been in conflict (Miège 1989; Hesmondhalgh 2007). Whereas for example content providers and copyright holder-organizations traditionally always have defended strong copyrights, hardware producers and a range of "cultural brokers" (as for example broadcasters) have had a more ambivalent stance towards strong copyright, sometimes defending it and sometimes questioning and challenging it. There seems, however, to have been a change in the media policy discourse: the former consensus of the need to defend strong copyright in order to support the media-, cultural- or creative sectors of the economy is starting to break down. In this part of the article, we want to point to three prominent examples of such a development. First, the trade organization CCIA (Computer \& Communications Industry Association) - with members such as Google, Yahoo, and Facebook - has adopted the principle of "open markets, open systems and full, fair and open competition" and actively promotes a less strict application of copyright in the online environment ${ }^{1}$. Second, we look at how such themes have been taken up on a trans-national European level within policy discourses in the European Union. And third, we analyse discussions in Sweden. This re-orientation in media policy discourses, we argue, should be understood against both the general background sketched earlier in the article (the relationship between property and commons) and the business practices of the powerful actors within the digital network economy.

CCIA is a trade and lobby organization that represents its members in both Washington and Brussels. Since 2007, the organization has published four studies that attempt to measure the size of the contribution of industries that are dependent on limits and exceptions in copyright law to the US and EU economies (see Rogers and Szamosszegi 2011). Following the methodology that WIPO (The World Intellectual Property Organization) has developed for measuring the copyright economy, these reports are trying to counterbalance the weight that has been put on strong copyrights in the policy discourse (WIPO 2003). The claim in the reports is that within a digital economy there is much greater need for exceptions and limitations to copyright since the technology that this

${ }^{1}$ www.ccianet.org 
economy is built on makes possible transfers and duplication of information on a massive scale that challenges a strict copyright regime. The reports argue that the Internet- and home electronicindustries are thus dependent on a sort of informational commons in order for their business models to be sustainable. Some of the members of CCIA also have been involved in controversies regarding copyright. So for example Google Inc. has stirred up many angry voices with projects such as Google Books, Google News, and YouTube. Several of CCIA's members are also in the business of exploiting user-generated content, something which is known to have copyright-related implications, both in regards to so-called remixing and in regards to the fact that there has been a discussion about the loss of control over uploaded content that users of platforms such as Facebook have experienced.

Within policy-making organisations such as the OECD and the EU there exists a striking enthusiasm over the new "opportunities" brought forward by the kind of companies that CCIA represents - social networking sites and digital service providers. There is a strong trust in the importance of these companies for the USA's and Europe's economic growth. The will to attract such businesses is strong, not least because of the "brand value" of attracting "the new" - for example in the form of server-halls owned by Google or Facebook (Jakobsson and Stiernstedt 2012). The immediate grounds for this political optimism is often unclear, since for example, the number of employees outside Silicon Valley - in these companies is relatively low. Furthermore, many of the companies in this sector have been notorious for tax planning and for hiding profits in offshore free tax havens (Drucker 2010). The direct economic contribution that these companies make to national economies is therefore disputable, and the hope lies rather in creating the image of a vibrant environment for new businesses.

Viviane Reding, former EU-commissioner for questions regarding information society and telecommunications, held her first speech on social networking sites in 2008. In the speech, she made clear that the "economic possibilities" of the informational economy rely on "openness" and "increased interactivity" (Reding 2008). The upside of new media companies is, according to Reding, that it takes "a minimum of financial investment" to make profits since new digital platforms give ordinary people, citizens of Europe, the "possibility" to "create new creative content" and redistribute content produced by others (ibid.). In many of Reding's other speeches delivered during the last years the same tendency can be found in the logic of her arguments. New economic possibilities in digital business models are put forward and these new business models are often connected to questions of openness: "We all know that the Internet has grown so rapidly because of its openness. This is why it has become such a valuable economic resource" (Reading 2009a).

Openness can of course mean many different things, for example, availability of Internet access, or freedom of speech in digital environments, etc. It can also mean, as it often does in Reding's speeches, the openness and accessibility of online content. One of the central issues emphasized by Reading is that policy makers have to "very speedily make it easier and more consumerfriendly to access digital content, we could lose the greatest opportunity we have ever had, both to maximise the amount of content available to consumers and to secure more efficient protection of right-holders. The stakes are high: the development of a wide range of new and innovative business models, which would boost the creativity and competitiveness of the European economy" (Reding 2009b).

Reding argues that without giving up on protection for copyrights holders, "openness" rather than "enclosures" is necessary for a competitive economy. For such openness to function, not least in "tackling of the consumer perspective" (Reding 2009b), European content creators and users must be able to feel trust. With less legislation, and less formal rights and responsibilities, trust and trustworthiness becomes an increasingly important currency in the digital economy, one that policymakers should enhance and empower (Reding 2009a; 2009b; 2009c; 2009d). In the new media economy copyrights holders and content creators have to trust that technology companies and new content distributors will find ways of reimbursing them economically. And in the new media economy citizens and users have to trust social networking sites and content platforms that they are not exploited in an unsustainable way or that their information is (at least to some degree) safe in the servers of the new media industries. The role for politicians is to participate in the creation and reproduction of trust, by licensing and arranging self-regulatory exercises for the actors of this new media industry. The digital economy is based on the community of platform providers, copyright holders, and users, rather than on the contractual relations between them. The model for regulation suggested by Reding is then, it seems, one that shares equally many characteristics with commons-based production as with production for the market.

In a similar vein, i2010, the program for reformulating and modernizing the EU's media policy, puts emphasis on the continued development of regulation that will promote "knowledge, content 
and creativity [in] advanced and open communication networks" (i2010 [COM 2005/229] emphasis added). Hence, policy measures are supposed to enhance the "common" (communication, cooperation, etc) and rather than to only uphold strong copyrights in the interests of rights-holders there is also a growing realization of the economic importance of a certain openness. One of the ways that this realization is articulated is through the need for "content" for the "European digital single market" (European Commission 2009). The Content Online-initiative, which is part of i2010, is premised on the suggestion that "content" is what is needed in order to fulfil the promise of the information society. What is perceived as the slow growth of information society services in the EU - presumably in relation to the USA - is believed to be dependent on the lack of access to content. The remedies for this, discussed within the initiative, touches both upon the monopolistic situation of the European collecting societies, which is supposed to hinder the realization of an online market, and upon the question of user-generated content that is seen as a source of cheap content emanating from new business models within the digital media industry.

In Sweden, the conservative party has pursued the same line of argument. In their program for "creation and innovation in digital environments" (presented in 2009), the Swedish conservatives put forward a new group that should be privileged and protected by the law. These are neither the creators or copyright holders nor the users and consumers, but rather the entrepreneurs. The main idea in the initiative is to make it easier for copyright holders to give up their economic and immaterial rights and to give the entrepreneurs that distribute and make content available more manoeuvring space (von Sydow and Schlingmann 2009). By adopting a media and cultural policy that establishes a larger cultural commons, the cultural sector can stimulate growth and innovation within the technology sector. The concrete examples of entrepreneurs mentioned in the documents discussed here are social networking sites (such as Facebook), new content distributors (such as YouTube, Voddler, Spotify) and search engines (such as Google). These companies do not need more enclosures, but on the contrary less (and instead more "commons") in order to make profit from the common cultural artefacts, common production, distribution, and the activities of Internet users.

\section{A New Media Policy Paradigm}

The article started with a discussion about the dialectical relationship between capital and commons as theorized by David Harvey, Michael Hardt, and Antonio Negri. In their view, capital creates value by enclosing the commons, which paradoxically means that capital is dependent on the continuation of the practices of the "commoners" and needs to not only allow but also enhance "commonality" among workers and citizens. For Harvey, Hardt and Negri, this poses a potential threat to the capitalist system as such. The paper then looked at how this relationship is relevant in relation to developments within the field of media policy, where discourses on openness and commons have come to supplement the traditional goal of strengthening property and ownership in immaterial goods. We conclude that this new direction in media policy is an attempt to integrate the commons, as they actually exist on the Internet, into capitalism and thus to neutralize the potential threat that the growth of digital commons, unencumbered by digital media business models, might present to the online market.

Van Cuilenberg \& McQuail (2003) have argued that the development of media policy has followed three paradigms. In the early $20^{\text {th }}$ century up until 1945 , media policies were formulated from the needs of the telecommunications industry. After 1945, the public service paradigm emerged, which oriented media policy around the concept of the "public interest". Following the rise of a more market-oriented liberalism in the beginning of the 1980's, the new paradigm that resulted kept the notion of the public interest, but began to formulate media policies more and more in economic terms. It is easy to see that the emphasis put on the generation of intellectual property within the media industries is part of this paradigm. We suggest that, due to the new market ideology coming from the digital industries, this rationale for media policy is now being renegotiated. We are not suggesting an entirely new paradigm, since the question if the public interest can be promoted by economic growth remains and neoliberalism has not come to an end, but we claim that what policymakers no longer perceive the unconditional support for intellectual property as the most marketoriented and economically efficient way of organizing the information economy. Increasingly policymakers have realized that the digital industries can create value using the content produced by the Internet users and the traditional cultural industries in a way that generates more value than the value produced by the copyright industries themselves. A more open policy in regards to intellectual property also means that the emerging intellectual commons on the Internet can be merged into the market and exploited by new and alternative business models. 
Michael Hardt (2010) claims that "the more the common is corralled as property, the more its productivity is reduced", but he also adds: "and yet expansion of the common undermines the relations of property in a fundamental and general way" (Hardt 2010, 136). We claim that the new direction within the current policy paradigm is an attempt to find a way out of this predicament for the media industries. The industry as well as policy-makers have, following the academic critique of copyright (e.g. Benkler 2006; Lessig 2008), realized that the current copyright regime is restricting innovation and economic creativity, especially within the hi-tech industry. Consequently they see a need for a less strict copyright regime. At the same time, however, they also realize that commonsbased production can undermine the value of the market in several areas. The solution can therefore not be to intensify the struggle for copyright, or to give up copyright, but to shift the arena for the struggle - from a regulated market to a, more or less, unregulated and local platform economy, where profits are distributed between platform owners and user communities. As long as the market is dominating the networks and platforms in which the "social production" (Benkler 2006) on the Internet takes place, the market still has the possibility to shape, package, and commodify the social production in a manner that has no need for intellectual copyrights. The losses that the market suffers in the copyright war can thus be recuperated in the platform economy, without questioning the role of property and ownership in securing a competitive economy. The commons are thus (re)integrated with capital for the time being.

\section{References}

Andrejevic, Mark. 2007. iSpy: Surveillance and Power in the Interactive Era. Lawrence: University Press of Kansas.

Benkler, Yochai. 2006. The Wealth of Networks: How Social Production Transforms Markets and Freedom. New Haven: Yale University Press.

Boyle, James. 2003. The Second Enclosure Movement and the Construction of the Public Domain. Law and Contemporary Problems 66, 33-74.

Caffentzis, George. 2010. The Future of 'the Commons': Neoliberalism's 'Plan B' or the Original Disaccumulation of Capital? New Formations 69 (1), 23-41.

COM 2005/229. i2010: A European Information Society for Growth and Employment: Communication from the Commission to the Council, the European Parliament, the European Economic and Social Committee and the Committee of the Regions.

Drucker, Jesse. 2010. The Tax Haven That's Saving Google Billions. Business Week, October 21. Accessed November 1, 2011. http://www.businessweek.com/magazine/content/10 44/b4201043146825 page 2.htm

Dyer-Witheford, Nick. 2002. E-capital and the Many-Headed Hydra. In Critical Perspectives on the Internet, edited by Greg Elmer, 129-164. Lanham: Rowman \& Littlefield Publishers.

European Commission. 2009. Creative Content in a European Digital Single Market: Challenges for the Future: A Reflection Document of DG INFSO and DG MARKT. Accessed March 18, 2010. http://ec.europa.eu/avpolicy/docs/other actions/col 2009/reflection paper.pdf

Flew, Terry. 2005. Creative Commons and the Creative Industries. Media and Arts Law Review 10 (4), 257-264.

Hardt, Michael, and Antonio Negri. 2009. Commonwealth. Cambridge: Harvard University Press.

Hardt, Michael. 2010. The Common in Communism. In The Idea of Communism, edited by Slavoi Žižek and Costas Douzinas, 131-144. London: Verso.

Harvey, David. 2003. The New Imperialism. Oxford: Oxford University Press.

Hesmondhalgh, David. 2007. The Cultural Industries. London: Sage.

Jakobsson, Peter, and Fredrick Stiernstedt. 2010. Pirates of Silicon Valley: State of Exception and Dispossession in Web 2.0. First Monday 15 (7). Accessed November 1, 2011. http://www.uic.edu/htbin/cgiwrap/bin/ojs/index.php/fm/article/view/2799/2577

Jakobsson, Peter, and Fredrick Stiernstedt. 2012. Time, Space and Clouds of Information: Data Center Discourse and the Meaning of Durability. In Cultures of Technology, Technologies of Culture, edited by Göran Bolin. New York: Routledge, forthcoming.

Kretschmer, Martin. 2005. Trends in Global Copyright. Global Media and Communication 1 (2): 231-237.

Lessig, Lawrence. 2004. Free Culture: How Big Media Uses Technology and the Law to Lock Down Culture and Control Creativity. New York: Penguin Press.

Lessig, Lawrence. 2008. Remix: Making Art and Commerce Thrive in the Hybrid Economy. New York: Penguin Press.

Luxemburg, Rosa. 1913/2003. The Accumulation of Capital. London: Routledge.

Marx, Karl. 1867/1976. Capital: A Critique of Political Economy: Volume 1. London: Penguin Books.

Miège, Bernard. 1989. The Capitalization of Cultural Production. New York: International General.

Neeson, J.M. 1993. Commoners: Common Right, Enclosure and Social Change in England, 1700-1820. Cambridge: Cambridge University Press.

Negri, Antonio. 2010. Communism: Some Thoughts on the Concept and Practice. In The Idea of Communism, edited by Slavoi Žižek and Costas Douzinas, 155-165. London: Verso.

Reding, Viviane. 2008. Social Networking Sites: Commissioner Reding Stresses their Economic and Societal Importance for Europe. Brussels 26 September 2008. Accessed November 1, 2011. http://europa.eu/rapid/pressReleasesAction.do?reference=MEMO/08/587\&format=HTML\&aged=0\&language=EN\&guiLa nguage $=$ en

Reding, Viviane. 2009a. Opening Speech at the Internet Governance Forum. Sharm El Sheikh, 15 November 2009. Accessed November 1, 2011. 
http://europa.eu/rapid/pressReleasesAction.do?reference=SPEECH/09/531\&format=HTML\&aged=0\&language=EN\&gui Language $=\mathrm{n}$

Reding, Viviane. 2009b. Bringing Down Walls and Barriers in the Digital World: Priorities for the European Digital Agenda. Visby Agenda: Creating Impact for an eUnion 2015. Visby/Gotland, 9 November 2009. Accessed November 1, 2011. http://europa.eu/rapid/pressReleasesAction.do?reference=SPEECH/09/519\&format=HTML\&aged=0\&language=EN\&gui Language=nl.

Reding, Viviane. 2009c. Viviane Reding Member of the European Commission in Charge of Information Society and Media: The Future of the Internet and Europe's Digital Agenda: Lunch Debate on the Future of the Internet and Europe's Digital Strategy. Brussels, 6 October 2009. Accessed November 1, 2011. http://europa.eu/rapid/pressReleasesAction.do?reference=SPEECH/09/446\&format=HTML\&aged=0\&language=EN\&gui Language $=$ en

Reding, Viviane. 2009d. Member of the European Commission Responsible for Information Society and Media Internet of the Future: What Policies to Make it Happen? Future of the Internet Conference. Prague, 11 May 2009. Accessed November 1, 2011.

http://europa.eu/rapid/pressReleasesAction.do?reference=SPEECH/09/231\&format=HTML\&aged=0\&language=EN\&gui Language $=\mathrm{nl}$

Rogers, Thomas, and Andrew Szamosszegi. 2011. Fair Use in the US Economy: Economic Contribution of Industries Relying on Fair Use. Washington: Computer \& Communications Industry Association. Accessed November 1, 2011. http://www.ccianet.org/CCIA/files/ccLibraryFiles/Filename/000000000085/FairUseStudy-Sep12.pdf

van Cuilenberg, Jan, and Dennis McQuail. 2003. Media Policy Paradigm Shift: Towards a New Communications Policy Paradigm. European Journal of Communication 18 (2): 181-207.

von Sydow, Henrik, and Per Schlingmann. 2009. Moderaterna ska jobba för en dynamisk upphovsrätt [The conservative party will work for a dynamic copyright]. Dagens Nyheter, December 17. Accessed November 1, 2011. http://www.dn.se/debatt/moderaterna-ska-jobba-for-en-dynamisk-upphovsratt

Wikström, Patrik. 2006. Reluctantly Virtual: Modelling Copyright Industry Dynamics. PhD Dissertation, University of Karlstad. Karlstadt: Karlstad University Studies.

WIPO. 2003. Guide on Surveying the Economic Contribution of the Copyright-Based Industries. Geneva: World Intellectual Property Organization.

\section{About the Authors}

Peter Jakobsson

is a PhD-Candidate in Media and Communication Studies at Södertörn University, Sweden. His international publications include articles in European Journal of Cultural Studies, First Monday, and Platform: Journal of Media \& Communication.

Fredrik Stiernstedt

is a PhD-Candidate in Media and Communication Studies at Södertörn University, Sweden. His dissertation concerns labour processes and the management of creativity in convergent media industries. His recent international publications include the chapter "Googleplex and Informational Culture", in Media Houses. Architecture, Media and the Production of Centrality. (Peter Lang 2010) and articles in The Radio Journal, First Monday, and Participations. 